\title{
Characteristics of Morphofunctional State of Paratrooper Cadets in the Process of CrossFit Training
}

\author{
Grygoriy Griban $^{1, *}$, Serhii Zhembrovskyi ${ }^{2}$, Vitalii Yahodzinskyi ${ }^{3}$, Tatiana Fedorchenko ${ }^{4}$, \\ Volodymyr Viknianskyi ${ }^{5}$, Pavlo Tkachenko ${ }^{6}$, Tetiana Samolenko ${ }^{7}$, Ruslan Malynoshevskyi ${ }^{4}$, \\ Svitlana Solohubova ${ }^{8}$, Olena Otravenko ${ }^{9}$, Maryna Hres ${ }^{10}$, Vasyl Prontenko ${ }^{11}$
}

\begin{abstract}
${ }^{1}$ Department of Physical Education and Sport Improvement, Zhytomyr Ivan Franko State University, Zhytomyr, Ukraine ${ }^{2}$ Department of Physical Education, Special Physical Training and Sport, The National Defense University of Ukraine named after Ivan Cherniakhovskyi, Kyiv, Ukraine

${ }^{3}$ Department of Physical Education, Special Physical Training and Sport, Odesa Military Academy, Odesa, Ukraine

${ }^{4}$ Institute of Problems on Education, National Academy of Pedagogical Sciences of Ukraine, Kyiv, Ukraine

${ }^{5}$ Department of Physical Education, Special Physical Training and Sport, Ivan Kozhedub Kharkiv National Air Force University, Kharkiv, Ukraine

${ }^{6}$ Department of Physical Education, Polissia National University, Zhytomyr, Ukraine

${ }^{7}$ Department of Physical Culture, Kyiv National University of Trade and Economics, Kyiv, Ukraine

${ }^{8}$ Department of Physical Education and Sports, Prydniprovska State Academy of Civil Engineering and Architecture, Dnipro, Ukraine

${ }^{9}$ Department of Theory and Methods of Physical Education, Luhansk Taras Shevchenko National University, Starobilsk, Ukraine

${ }^{10}$ Department of Physical Education, Zhytomyr Polytechnic State University, Zhytomyr, Ukraine

${ }^{11}$ Department of Physical Education, Special Physical Training and Sport, S. P. Koroliov Zhytomyr Military Institute, Zhytomyr, Ukraine
\end{abstract}

Received April 3, 2021; Revised June 2, 2021; Accepted June 20, 2021

\section{Cite This Paper in the following Citation Styles}

(a): [1] Grygoriy Griban, Serhii Zhembrovskyi, Vitalii Yahodzinskyi, Tatiana Fedorchenko, Volodymyr Viknianskyi, Pavlo Tkachenko, Tetiana Samolenko, Ruslan Malynoshevskyi, Svitlana Solohubova, Olena Otravenko, Maryna Hres, Vasyl Prontenko, "Characteristics of Morphofunctional State of Paratrooper Cadets in the Process of CrossFit Training," International Journal of Human Movement and Sports Sciences, Vol. 9, No. 4, pp. 772 - 780, 2021. DOI: 10.13189/saj.2021.090423.

(b): Grygoriy Griban, Serhii Zhembrovskyi, Vitalii Yahodzinskyi, Tatiana Fedorchenko, Volodymyr Viknianskyi, Pavlo Tkachenko, Tetiana Samolenko, Ruslan Malynoshevskyi, Svitlana Solohubova, Olena Otravenko, Maryna Hres, Vasyl Prontenko (2021). Characteristics of Morphofunctional State of Paratrooper Cadets in the Process of CrossFit Training. International Journal of Human Movement and Sports Sciences, 9(4), 772 - 780. DOI: 10.13189/saj.2021.090423.

Copyright $\odot 2021$ by authors, all rights reserved. Authors agree that this article remains permanently open access under the terms of the Creative Commons Attribution License 4.0 International License

\begin{abstract}
The CrossFit training's influence on the morphofunctional state (morphological and functional indicators) of cadets who are the future officers of the Ukrainian Air Assault Forces is studied in the paper. The research was conducted at the Odesa Military Academy (Ukraine) at the Faculty of Air Assault Forces training in 2018-2020. 90 male cadets took part in the research. We formed two groups: experimental group (EG, $\mathrm{N}=45)$, the cadets of which were training in the academy CrossFit classes during sports and mass work, and control group ( $C G, N=45$ ), the cadets of which were training according to the traditional classes of physical training. The morphological (conditional) indicators of cadets were
\end{abstract}

assessed in terms of such indicators as height, body weight, handgrip test, body mass index, power index. Their functional state was examined in terms of the following indicators: heart rate at rest, blood pressure, vital capacity, life index, Robinson index, and heart rate recovery after physical activity. The positive influence of CrossFit classes on the morphofunctional state of paratrooper cadets was established. In senior years of study, the indicators of the cadets of EG were significantly $(p<0.05-0.001)$ more advanced than those of the cadets of CG by all indicators studied. The most pronounced influence of CrossFit training was found in terms of the indicators of the cardiovascular system, body weight, and power qualities of 
cadets. A high level of the morphofunctional state of future officers of the Ukrainian Air Assault Forces in the educational process will increase the efficiency of the future combat activity.

Keywords Morphological and Functional Indicators, Cadets, Paratroopers, CrossFit

\section{Introduction}

The analysis of the experience gained by the Ukrainian Armed Forces in an armed conflict and the experience of conducting hostilities by the leading countries shows that The Ukrainian Air Assault Forces (AAF) are most consistent with the modern requirements of combined arms operation. They must have high operational mobility, deploy combat operations within a short time, carry out maneuvers in a short time, and boldly and suddenly strike at vital enemy locations [1, 2, 3]. Professional military (combat) activity of AAF officers takes place in extreme conditions and this complicates the performance of assigned tasks. It is characterized by diversity, intensity, and specificity, significant physical activity, which generally places high demands on physical fitness of military personnel, in particular, it requires the universality, the readiness to act in any situation, environment, and time $[4,5,6,7]$.

The scientists $[8,9,10,11]$ point out that physical training in the system of combat training of military personnel occupies an important place as the main subject of combat training. It affects all the components of combat efficiency. The objective basis of this is the reflection of physical qualities, motor skills and biological features of the organism, formed in the process of physical training, in combat efficiency. The military personnel with a high level of power, endurance, speed, and agility have advantages in combat situations over those with a lower level of these qualities due to various elements of professional military activity $[12,13,14,15]$.

CrossFit, the essence of which is to perform simple high-intensity physical exercises for the development of various muscle groups by circuit training, can be a quite effective means of physical training for AAF officers, as well as for the cadets of military higher education institutions [16, 17]. The scientists [18, 19] note that the specificity of CrossFit is precisely the rejection of any specialization. The combination of weightlifting, gymnastics, running, kettlebell lifting and exercises with one's own weight gives a wide range of different workouts for each day, which makes it possible to add variety and make the training process much more interesting and effective.

The uniqueness of CrossFit is provided by the variability of the exercise combinations, mainly power and endurance development, and its advantages include minimum costs for equipment (most exercises are performed with the weight of one's own body, it is possible to use improvised means and natural conditions); possibility of applying it in the conditions of deficit of time and limited space, in the field; excluding the possibility of adaptation to stress by means of variation; accessibility for military personnel with different levels of physical fitness [20, 21].

\subsection{The Aim}

The aim of the study is to investigate the influence of CrossFit training on the morphofunctional state of cadets who are the future officers of the Ukrainian Air Assault Forces.

\section{Materials and Methods}

The research was conducted at the Odesa Military Academy (Ukraine) at the Faculty of Air Assault Forces training in 2018-2020. 90 male cadets aged 17-20 took part in the research. We formed two groups: experimental group ( $\mathrm{EG}, \mathrm{N}=45$ ), the cadets of which were training in the academy CrossFit classes during sports and mass work, and control group ( $\mathrm{CG}, \mathrm{N}=45$ ), the cadets of which were training according to the traditional classes of physical training.

The experimental group involved first-year cadets, who wanted to do CrossFit during sports and mass work under the guidance of a professional coach at the beginning of their studies at the academy. And the cadets of the control group were training according to the traditional program during sports and mass work (according to the developed options: short-distance or long-distance running or bar strength exercises). Sports and mass work at the academy was held 3 times a week: a one-hour training twice on weekdays and a three-hour training on a day off. The only difference between the EG and CG was the content of training during sports and mass work. The total number of hours of physical training per week, including academic sessions, morning exercises, and sports and mass work, did not differ between the EG and CG.

CrossFit offers a significant variety of activities that contain elements of different sports and exercises. That is, selecting different exercises and regulating physical activity (changing the weight, duration of exercises, number of sets and reps, duration of rest between sets and exercises, and other indicators), CrossFit training increases cadets' interest in physical exercises and forms a positive motivation to the improvement of physical training results. This significantly affects the morphofunctional state of paratroopers and their future professional activities performance.

The exercises that the cadets performed during the 
CrossFit training were planned taking account of the level of the cadets' training. This is an example of a set for the EG cadets' training in the 1st year of study:

1. Pull-ups -5-6 times.

2. Jumping squats $-8-10$ times.

3. Push-ups $-10-12$ times.

4. Sit-ups - 10-12 times.

A set should be repeated 2-3 times with 10-15 seconds of rest between exercises and 20-30 seconds between sets.

In the 4th year of study this set looks in the following way:

1. Pull-ups $-8-10$ times.

2. Jumping squats $-15-20$ times.

3. Push-ups $-15-20$ times.

4. Sit-ups -15-20 times.

A set should be repeated 6-7 times with no rest between exercises or sets.

Another example of a set for the first-year cadets:

1. A $16 \mathrm{~kg}$ kettlebell snatch $-10-15$ times each arm.

2. Box jumps $-8-10$ times.

3. Bar pull-overs $-4-5$ times.

4. Bar dips $-8-10$ times.

A set should be repeated 3-4 times with 15-20 seconds of rest between exercises and 20-30 seconds between sets.

In the 4th year of study, this set looks as follows:

1. A $24 \mathrm{~kg}$ kettlebell snatch $-15-20$ times each arm.

2. Box jumps $-15-20$ times.

3. Muscle-ups $-6-8$ times.

4. Bar-dips $-15-20$ times.

5. $24 \mathrm{~kg}$ kettlebell lunges -15 times each arm.

6. Rope-climbing (without the help of legs).

A set should be repeated 5-6 times with no rest between exercises or sets.

CrossFit exercises are not unique, but the features of their application (rest intervals reduction, increase in intensity) contribute to a significant improvement of the morphofunctional state of the EG cadets. According to the traditional system of physical training at the academy, CrossFit is not used because the regulations for physical training of the cadets of Ukrainian higher military educational institutions do not involve it.

The term "morphofunctional state" consists of two parts: "morpho" and "functional". Morpho is Latin for "form". Morphology is the science that studies the structure and shape of the human body. Morphological indicators (indicators that characterize the shape of the human body) are height, body weight, the circumference of body parts, the proportions of the body parts development, body composition, muscle development, the amount of fat stored, etc. They are also called anthropometric or conditional indicators.

The functional state is a state of a living system that determines the level of vital activity of the organism, the systemic response to physical activity, and allows assessing the level of the organism adaptation to the environment (living conditions, professional activities, physical activity, etc.). The functional state is defined as an integral characteristic of functional indicators of various organs and body systems (cardiovascular, respiratory, and others).

The morphological (conditional) indicators assessed in the study included height, body weight, handgrip test, body mass index, power index. The functional indicators involved heart rate at rest, blood pressure, vital capacity, life index, Robinson index, and heart rate recovery after physical activity.

The body weight of cadets and their body composition (body fat content; the mass of tissues that do not contain fat; water content) was assessed using analyzing scales "TANITA - BC-418MA" by bioimpedance method (the electrical resistance of the body). The fat component was determined in $\mathrm{kg}$ and as a percentage of body weight. The compliance with age standards and dynamics of the fat component during the study at the academy were assessed. During the handgrip test, a cadet squeezed the hand dynamometer (DRP-90; division value - $2 \mathrm{~kg}$ ) alternately with each hand, holding the arm extended parallel to the ground. The best result was chosen out of three tests performed with each hand.

The heart rate and blood pressure of the cadets at rest were studied by the medical staff of the sanitary unit of the Military Academy using a blood pressure monitor ("SANITAS", SBM-07). A cadet was in a sitting position at rest for 5 minutes. The cuff was wrapped around an upper left arm at the level of the heart, the body was relaxed. The vital capacity of the lungs was determined using an electronic spirometer ("SPIROPRO", BTL-08) in a standing position at rest. The duration of recovery processes in the body of cadets was estimated by the Martin-Kushelevsky test - the assessment of the recovery time of heart rate after a standard exercise (20 squats in 30 s). The heart rate was measured at rest before the test, and after exercise, it was measured at each minute of recovery. The duration of recovery of heart rate was recorded with a stopwatch. The study of functional indicators of cadets was carried out at the same time of day (15 minutes after waking up). All the EG and CG cadets were in the same conditions throughout the study period: 8 hours of sleep, three meals a day, no alcohol or other chemicals that can significantly affect the results of the experiment. In case of illness, a cadet was reported to the medical staff, and his examination was postponed until the moment of his full recovery.

The body mass index (BMI) was defined as the ratio of the body weight to body height and is expressed in $\mathrm{kg} / \mathrm{m}^{2}$. The life index (LI) was determined by the ratio of vital capacity to body weight in $\mathrm{ml} / \mathrm{kg}$. The power index (PI) was designated by the ratio of the wrist power to body weight in percent. The Robinson index (RI) was defined in standard units by the product of the heart rate and 
systolic blood pressure which was divided by 100 . The evaluation of the heart rate recovery (HRR) was held after 20 squats in 30 seconds. The study of the morphological (conditional) and functional indicators of paratrooper cadets was conducted in the medical unit of the Odesa Military Academy during regular medical examinations by medical staff.

Research methods: theoretical analysis and generalization of literature sources, pedagogical observation, medical and biological methods, the methods of mathematical statistics. Theoretical analysis and generalization of literature sources were used to obtain information on the research topic. Using this method, we got acquainted with the research of leading scientists and scientifically substantiated the factual material obtained during the study. During the work on the article, we have processed 34 literary publications, which are part of the scientometric databases Scopus, PubMed, Web of Science Core Collection, and others.

Pedagogical observation as a method of scientific research was used to assess the efficiency of the traditional system of physical training at Military Academy, to analyse the educational activities of paratrooper cadets and their military professional (combat) activities, to study the impact of CrossFit on the morphological and functional indicators of cadets. The main attention was paid to the features of performing CrossFit exercises, the correctness of exercises, and the dosage of activities, which had to comply with the physical fitness of cadets, the body's response to the load, and organizational and methodological requirements in classes.

The medical and biological methods include the methods, used to determine the morphological (conditional) indicators (height, body weight, handgrip test) and functional indicators (heart rate at rest, blood pressure, vital capacity, life index, Robinson index, and heart rate recovery after physical activity) of cadets.

The methods of mathematical statistics were applied to correctly process the data and identify the difference between the studied indicators. The results were reported as Mean \pm SD. The authenticity of the difference between the indicators was determined with the help of the Student's t-test. The statistical significance for all statistical tests was set at $\mathrm{p}<0.05$. All statistical analyses were performed with the SPSS software, version 21.

This study complies with the ethical standards of the Order of the Minister of Defense of Ukraine «On Approval of the Regulation on the Organization of Scientific and Technical Activity in the Armed Forces of Ukraine» No. 385 dated 27.07.2016. The procedure for organizing the study, the stages, the venue, and the permission for the involvement of cadets in the research were previously agreed with The Committee on Compliance with Academic Integrity and Ethics of the Odesa Military Academy (Protocol No. 5 dated
27.05.2019). The prior consent to participate in the experiment was obtained from all the participants.

\section{Results}

The study of cadets' height of EG and CG showed that a significant difference between the indicators of the cadets in all years of study was not recorded $(p>0.05)$. The analysis of the dynamics of cadets' height during the studying showed that in both groups the average values increased, but the indicators of cadets of the 1st and 4th year did not differ significantly (Table 1). Analyzing the body weight, it should be noted that in the 1 st -3 rd years of study, there was no significant difference between the indicators $(p>0.05)$. Only in the 4 th year, the body weight of the cadets of EG was significantly lower in comparison with $\mathrm{CG}$ by $4.5 \mathrm{~kg}(\mathrm{p} \leq 0.05)$. During the studying, the body weight of cadets of both groups increased. In EG, the difference between the indicators of the 1st and 4th years was $1.9 \mathrm{~kg}$ ( $>>0.05)$, and in $\mathrm{CG}$, the body weight of cadets was increased by $6 \mathrm{~kg}$ significantly $(\mathrm{p} \leq 0.001)$. It is important to note that the body weight of the EG cadets was increased but the fat component was not changed (at the beginning and end of the study it accounted for $9 \%$ of body weight), and the body weight of the CG cadets was increased due to an increase in fat component from 9 to $13 \%$.

Table 1. The comparative analysis of the height, weight, and body mass index of cadets of EG and CG $(\mathrm{N}=90)$

\begin{tabular}{|c|c|c|c|c|}
\hline \multirow{2}{*}{$\begin{array}{c}\text { Year } \\
\text { of } \\
\text { study }\end{array}$} & EG $(\mathbf{N}=\mathbf{4 5})$ & CG $(\mathbf{N}=\mathbf{4 5})$ & \multicolumn{2}{|c|}{$\begin{array}{c}\text { Significance of } \\
\text { difference }\end{array}$} \\
\cline { 2 - 5 } & Mean \pm SD & Mean \pm SD & t & p \\
\hline 1st & $175.7 \pm 1.25$ & $176.0 \pm 1.21$ & 0.17 & $\mathrm{p}>0.05$ \\
\hline 2nd & $175.9 \pm 1.27$ & $176.1 \pm 1.23$ & 0.11 & $\mathrm{p}>0.05$ \\
\hline 3rd & $176.2 \pm 1.26$ & $176.3 \pm 1.24$ & 0.06 & $\mathrm{p}>0.05$ \\
\hline 4th & $176.4 \pm 1.25$ & $176.5 \pm 1.23$ & 0.06 & $\mathrm{p}>0.05$ \\
\hline \multicolumn{5}{|c|}{ Body weight, kg } \\
\hline 1st & $69.8 \pm 1.17$ & $70.2 \pm 1.03$ & 0.26 & $\mathrm{p}>0.05$ \\
\hline 2nd & $71.2 \pm 1.13$ & $72.9 \pm 1.01$ & 1.12 & $\mathrm{p}>0.05$ \\
\hline 3rd & $71.5 \pm 1.12$ & $74.4 \pm 0.99$ & 1.94 & $\mathrm{p}>0.05$ \\
\hline 4th & $71.7 \pm 1.07 *$ & $76.2 \pm 0.97$ & 3.12 & $\mathrm{p} \leq 0.05$ \\
\hline \multicolumn{5}{|c|}{ Body mass index, kg/m ${ }^{2}$} \\
\hline 1st & $22.66 \pm 0.23$ & $22.67 \pm 0.21$ & 0.03 & $\mathrm{p}>0.05$ \\
\hline 2nd & $23.04 \pm 0.17 *$ & $23.52 \pm 0.16$ & 2.06 & $\mathrm{p} \leq 0.05$ \\
\hline 3rd & $23.01 \pm 0.17 * * *$ & $24.01 \pm 0.17$ & 4.16 & $\mathrm{p} \leq 0.001$ \\
\hline 4th & $23.13 \pm 0.18 * * *$ & $24.42 \pm 0.15$ & 5.51 & $\mathrm{p} \leq 0.001$ \\
\hline
\end{tabular}

Note: N: number of subjects; Mean: arithmetical average; SD: standard deviation; $t$ : t-test value, $\mathrm{p}$ : the significance of the difference between the indicators of $\mathrm{EG}$ and $\mathrm{CG}$; * - statistical significance of the difference on the level $\mathrm{p} \leq 0.05 ; * *$ - statistical significance of the difference on the level $\mathrm{p} \leq 0.01 ; * * *$ - statistical significance of the difference on the level $\mathrm{p} \leq 0.001$ 
The study of BMI shows that in the 1st year, a significant difference between the indicators of EG and CG was not found $(p>0.05)$. In the $2 n d-4$ th years, the cadets who were engaged in CrossFit were found to have significantly more improved BMI. It was found that in the 2nd year, the BMI of the cadets of EG was more improved by $0.48 \mathrm{~kg} / \mathrm{m}^{2}$ significantly $(\mathrm{p} \leq 0.05)$, in the $3 \mathrm{rd}$ year - by $1 \mathrm{~kg} / \mathrm{m}^{2}(\mathrm{p} \leq 0.001)$, in the 4 th year - by $1.29 \mathrm{~kg} / \mathrm{m}^{2}$ $(p \leq 0.001)$. During the studying, there was the trend of increasing BMI of the cadets of both groups, but the difference between the indicators of the cadets of EG of the $1 \mathrm{st}$ and 4 th years was $0.47 \mathrm{~kg} / \mathrm{m}^{2}(\mathrm{p}>0.05)$, and in $\mathrm{CG}$ $-1.75 \mathrm{~kg} / \mathrm{m}^{2}(\mathrm{p} \leq 0.001)$, which made it possible to state a more positive impact of CrossFit classes on the physical development of paratrooper cadets in comparison with the traditional system of physical training.

The assessment of the functional state of the respiratory system of cadets was carried out according to the indicators of the vital capacity (VC) and LI. Thus, the analysis of the VC indicators showed that in the 1st, 2nd, and 3rd years, a significant difference between the indicators of the cadets of EG and CG was not detected $(\mathrm{p}>0.05)$ (Table 2). In the 4th year, the functional capabilities of the respiratory system of the cadets of EG were more developed than those of the cadets of CG by $271.5 \mathrm{ml}$ significantly $(\mathrm{p} \leq 0.05)$. During the cadets' studying, the VC in both groups was improved, but in EG, the indicators of the 4th-year cadets were more increased than the indicators of the 1 st-year cadets by $353.4 \mathrm{ml}$ significantly $(\mathrm{p} \leq 0.05)$, whereas in Group 2 , the difference was $97.8 \mathrm{ml}(\mathrm{p}>0.05)$.

Table 2. The comparative analysis of the functional capabilities of the respiratory system of cadets of $E G$ and $C G(N=90)$

\begin{tabular}{|c|c|c|c|c|}
\hline \multirow{2}{*}{$\begin{array}{c}\text { Year } \\
\text { of } \\
\text { study }\end{array}$} & EG (N=45) & CG $(\mathbf{N}=\mathbf{4 5 )}$ & \multicolumn{2}{c|}{$\begin{array}{c}\text { Significance of } \\
\text { difference }\end{array}$} \\
\cline { 2 - 5 } & Mean \pm SD & Mean \pm SD & $\mathbf{t}$ & $\mathbf{p}$ \\
\hline \multicolumn{5}{|c|}{ Vital capacity, ml } \\
\hline 1st & $4135.2 \pm 84.27$ & $4119.3 \pm 84.64$ & 0.13 & $\mathrm{p}>0.05$ \\
\hline 2nd & $4297.8 \pm 78.13$ & $4168.5 \pm 82.38$ & 1.08 & $\mathrm{p}>0.05$ \\
\hline 3rd & $4391.5 \pm 74.06$ & $4190.9 \pm 80.07$ & 1.84 & $\mathrm{p}>0.05$ \\
\hline 4th & $4488.6 \pm 72.71^{*}$ & $4217.1 \pm 79.75$ & 2.52 & $\mathrm{p} \leq 0.05$ \\
\hline \multicolumn{5}{|c|}{ Life index, m1/kg } \\
\hline 1st & $59.24 \pm 1.24$ & $58.68 \pm 1.23$ & 0.32 & $\mathrm{p}>0.05$ \\
\hline 2nd & $60.36 \pm 1.19$ & $57.18 \pm 1.21$ & 1.87 & $\mathrm{p}>0.05$ \\
\hline 3rd & $61.42 \pm 1.15^{* *}$ & $56.10 \pm 1.17$ & 3.24 & $\mathrm{p} \leq 0.01$ \\
\hline 4th & $62.60 \pm 1.12^{* * *}$ & $55.34 \pm 1.14$ & 4.54 & $\mathrm{p} \leq 0.001$ \\
\hline
\end{tabular}

Note: N: number of subjects; Mean: arithmetical average; SD: standard deviation; $t$ : $t$-test value, $p$ : the significance of the difference between the indicators of EG and CG; * - statistical significance of the difference on the level $\mathrm{p} \leq 0.05 ; * *$ - statistical significance of the difference on the level $\mathrm{p} \leq 0.01$; $* * *$ - statistical significance of the difference on the level $\mathrm{p} \leq 0.001$

The comparative analysis of the LI of the cadets of EG and CG showed that in the 1st and 2nd years, the indicators did not differ significantly $(\mathrm{p}>0.05)$, and in the 3rd and 4th years of study, the LI of cadets, who were engaged in CrossFit, was significantly more improved by 5.32 and $7.26 \mathrm{ml} / \mathrm{kg}$ respectively $(\mathrm{p} \leq 0.01 ; \mathrm{p} \leq 0.001)$. During the studying, changes in the LI in EG were characterized by positive dynamics - the indicators of 4th-year cadets were more improved in comparison with the indicators of the 1st-year cadets by $3.36 \mathrm{ml} / \mathrm{kg}$ ( $p>0.05$ ), and in CG, there was a trend of deteriorating functional capabilities of the respiratory system - the average value of the LI of the 4th-year cadets was significantly worse than that of the 1st-year cadets by 3.34 $\mathrm{ml} / \mathrm{kg}$.

The study of the handgrip test indicators of the cadets of EG and CG found that in the 1st, 2nd and 3rd years, the level of arm strength of the cadets of both groups did not differ significantly ( $>0.05)$ (Table 3$)$. In the 4 th year, the cadets who were engaged in CrossFit showed more improved handgrip test results by $4.6 \mathrm{~kg}$ significantly $(p \leq 0.05)$, which indicated a more efficient impact of CrossFit on the arm strength of paratrooper cadets. During the studying, the power performance of the cadets of both groups was improved significantly $(p \leq 0.05)$, but the difference between the performance of the $1 \mathrm{st}$ and 4th-year cadets was $2.6 \mathrm{~kg}$ in the CG, and $7.4 \mathrm{~kg}$ in the EG, which emphasized the effect of CrossFit training.

Table 3. The comparative analysis of the muscular system capabilities of cadets of EG and CG $(\mathrm{N}=90)$

\begin{tabular}{|c|c|c|c|c|}
\hline \multirow{2}{*}{$\begin{array}{c}\text { Year of } \\
\text { study }\end{array}$} & EG $(\mathbf{N}=\mathbf{4 5})$ & $\mathbf{C G}(\mathbf{N}=\mathbf{4 5})$ & $\begin{array}{c}\text { Significance of } \\
\text { difference }\end{array}$ \\
\cline { 2 - 5 } & Mean \pm SD & Mean \pm SD & $\mathbf{t}$ & $\mathbf{p}$ \\
\hline \multicolumn{5}{|c|}{ Handgrip test, $\mathrm{kg}$} \\
\hline 1st & $41.2 \pm 1.19$ & $41.4 \pm 1.13$ & 0.12 & $\mathrm{p}>0.05$ \\
\hline 2nd & $43.7 \pm 1.17$ & $42.2 \pm 1.09$ & 0.94 & $\mathrm{p}>0.05$ \\
\hline 3rd & $46.1 \pm 1.12$ & $43.5 \pm 1.04$ & 1.70 & $\mathrm{p}>0.05$ \\
\hline 4th & $48.6 \pm 1.14 *$ & $44.0 \pm 1.05$ & 2.97 & $\mathrm{p} \leq 0.05$ \\
\hline \multicolumn{5}{|c|}{ Power index, \% } \\
\hline 1st & $59.03 \pm 1.42$ & $58.97 \pm 1.34$ & 0.03 & $\mathrm{p}>0.05$ \\
\hline 2nd & $61.38 \pm 1.37$ & $57.89 \pm 1.27$ & 1.87 & $\mathrm{p}>0.05$ \\
\hline 3rd & $64.47 \pm 1.31 * *$ & $58.23 \pm 1.28$ & 3.41 & $\mathrm{p} \leq 0.01$ \\
\hline 4th & $\begin{array}{c}67.78 \pm 1.24 * * \\
*\end{array}$ & $57.74 \pm 1.25$ & 5.70 & $\mathrm{p} \leq 0.00$ \\
\end{tabular}

Note: N: number of subjects; Mean: arithmetical average; SD: standard deviation; $t$ : t-test value, $\mathrm{p}$ : the significance of the difference between the indicators of EG and CG; * - statistical significance of the difference on the level $\mathrm{p} \leq 0.05 ; * *$ - statistical significance of the difference on the level $\mathrm{p} \leq 0.01 ; * * *$ - statistical significance of the difference on the level $\mathrm{p} \leq 0.001$

A comparison of the PI of the cadets of EG and CG showed that in all years of study, the PI of the cadets of EG was more developed than that of the cadets of CG. However, a significant difference was found only in the 3rd and 4th years - it accounted for $6.24 \%$ and $10.04 \%$ $(p \leq 0.01 ; p \leq 0.001)$. During the studying, the PI of the cadets of EG was characterized by positive dynamics the indicators of the 4th-year cadets were more improved 
than those of the 1st-year cadets by $8.75 \%$ significantly $(\mathrm{p} \leq 0.05)$. And in CG, there was an insignificant deterioration of the PI by $1.23 \%$ ( $>>0.05)$.

Table 4. The comparative analysis of the functional capabilities of the cardiovascular system of cadets of EG and CG $(\mathrm{N}=90)$

\begin{tabular}{|c|c|c|c|c|}
\hline \multirow{2}{*}{$\begin{array}{l}\text { Year of } \\
\text { study }\end{array}$} & \multirow{2}{*}{$\begin{array}{l}\text { EG }(\mathrm{N}=45) \\
\text { Mean } \pm \text { SD }\end{array}$} & \multirow{2}{*}{$\begin{array}{l}\mathrm{CG}(\mathrm{N}=45) \\
\text { Mean } \pm \text { SD }\end{array}$} & \multicolumn{2}{|c|}{$\begin{array}{l}\text { Significance of } \\
\text { difference }\end{array}$} \\
\hline & & & $\mathbf{t}$ & $\mathbf{p}$ \\
\hline \multicolumn{5}{|c|}{ Heart rate at rest, $\mathrm{bpm}^{-1}$} \\
\hline 1 st & $71.3 \pm 0.83$ & $71.4 \pm 0.85$ & 0.08 & $\mathrm{p}>0.05$ \\
\hline 2nd & $69.5 \pm 0.79$ & $70.6 \pm 0.82$ & 0.94 & $\mathrm{p}>0.05$ \\
\hline $3 \mathrm{rd}$ & $67.9 \pm 0.78$ & $70.1 \pm 0.79$ & 1.98 & $\mathrm{p}>0.05$ \\
\hline 4th & $66.5 \pm 0.77 * *$ & $69.7 \pm 0.78$ & 2.92 & $\mathrm{p} \leq 0.01$ \\
\hline \multicolumn{5}{|c|}{ Systolic blood pressure, $\mathrm{mmHg}$} \\
\hline 1 st & $122.6 \pm 1.19$ & $122.4 \pm 1.17$ & 0.12 & $\mathrm{p}>0.05$ \\
\hline 2 nd & $121.4 \pm 1.18$ & $121.8 \pm 1.16$ & 0.21 & $\mathrm{p}>0.05$ \\
\hline $3 \mathrm{rd}$ & $120.6 \pm 1.16$ & $121.3 \pm 1.16$ & 0.39 & $\mathrm{p}>0.05$ \\
\hline 4th & $119.8 \pm 1.15$ & $120.8 \pm 1.15$ & 0.61 & $\mathrm{p}>0.05$ \\
\hline \multicolumn{5}{|c|}{ Diastolic blood pressure, $\mathrm{mmHg}$} \\
\hline 1 st & $70.5 \pm 0.87$ & $70.4 \pm 0.82$ & 0.08 & $\mathrm{p}>0.05$ \\
\hline 2nd & $70.3 \pm 0.86$ & $70.2 \pm 0.84$ & 0.09 & $\mathrm{p}>0.05$ \\
\hline $3 \mathrm{rd}$ & $70.0 \pm 0.84$ & $70.1 \pm 0.82$ & 0.11 & $\mathrm{p}>0.05$ \\
\hline 4 th & $69.8 \pm 0.81$ & $70.1 \pm 0.80$ & 0.26 & $\mathrm{p}>0.05$ \\
\hline \multicolumn{5}{|c|}{ Robinson index, c.u. } \\
\hline 1 st & $87.41 \pm 1.18$ & $87.39 \pm 1.15$ & 0.01 & $\mathrm{p}>0.05$ \\
\hline 2 nd & $85.37 \pm 1.16$ & $85.99 \pm 1.14$ & 0.38 & $\mathrm{p}>0.05$ \\
\hline $3 \mathrm{rd}$ & $81.89 \pm 1.12$ & $85.03 \pm 1.13$ & 1.97 & $\mathrm{p}>0.05$ \\
\hline 4 th & $79.66 \pm 1.05^{*}$ & $84.19 \pm 1.07$ & 2.85 & $\mathrm{p} \leq 0.05$ \\
\hline \multicolumn{5}{|c|}{ Heart rate recovery, $\mathrm{s}$} \\
\hline 1 st & $128.9 \pm 2.67$ & $129.6 \pm 2.71$ & 0.18 & $\mathrm{p}>0.05$ \\
\hline 2 nd & $121.4 \pm 2.51$ & $123.0 \pm 2.57$ & 0.45 & $\mathrm{p}>0.05$ \\
\hline $3 \mathrm{rd}$ & $109.8 \pm 2.35$ & $115.4 \pm 2.44$ & 1.65 & $\mathrm{p}>0.05$ \\
\hline 4th & $97.5 \pm 2.28 *$ & $107.3 \pm 2.36$ & 2.99 & $\mathrm{p} \leq 0.05$ \\
\hline
\end{tabular}

Note: N: number of subjects; Mean: arithmetical average; SD: standard deviation; $\mathrm{t}$ : t-test value, $\mathrm{p}$ : the significance of the difference between the indicators of EG and CG; * - statistical significance of the difference on the level $\mathrm{p} \leq 0.05 ; * *$ - statistical significance of the difference on the level $\mathrm{p} \leq 0.01 ; * * *$ - statistical significance of the difference on the level $\mathrm{p} \leq 0.001$

The study of the heart rate at rest defined that during the 1 st - 3rd years of study, the heart rate of the cadets of EG and CG did not differ significantly ( $p>0.05)$. In the 4 th year, the heart rate of the cadets who attended the academy CrossFit class was significantly more improved in comparison with the cadets who were training according to the traditional system of physical training, by $3.2 \mathrm{bpm}^{-1}(\mathrm{p} \leq 0.01)$ (Table 4). This suggests that CrossFit training has a positive effect on the functional abilities of the cardiovascular system of paratrooper cadets. During the studying, the heart rate of the cadets of both groups was improved significantly $(\mathrm{p} \leq 0.01)$, but the difference between the indicators of the cadets of the 4th and 1st years was 1.7 bpm-1 in CG, and 4.8 bpm-1 in EG. As a result of the study of blood pressure, it was found that, despite the trend of improving both systolic and diastolic blood pressure of the cadets of both groups, the indicators of the cadets of EG and CG did not differ significantly in all years ( $p>0.05)$ (Table 4).

The estimation of the RI showed that in the 1st - 3rd years, the indicators of the cadets of EG and CG did not differ significantly $(\mathrm{p}>0.05)$, and the 4th-year cadets of EG were found to have more improved indicators of the RI by 4.53 c.u. significantly $(\mathrm{p} \leq 0.05)$. The analysis of the dynamics of the RI during the cadets' studying showed that the average values of the RI were significantly improved in both groups: by 7.75 c.u. in EG $(\mathrm{p} \leq 0.05)$ and 3.2 c.u. in CG $(\mathrm{p} \leq 0.01)$. This suggests a more effective impact of CrossFit training in comparison with the traditional system of physical training concerning the improvement of the functional abilities of the cardiovascular system of cadets.

Comparing the HRR of cadets after physical activity, it was found that in the 1st, 2nd, and 3rd years, there was no significant difference in the indicators of the cadets of EG and CG ( $>0.05)$. In the 4 th year, the cadets who attended the CrossFit classes were found to have more developed indicators significantly in comparison with the cadets who were studying according to the traditional system of physical training by $9.8 \mathrm{~s}(\mathrm{p} \leq 0.05)$, which confirmed our previous conclusions about the positive impact of CrossFit training on the functional indicators of the cardiovascular system of paratrooper cadets.

\section{Discussion}

The scientists $[1,22,23,24]$ note that modern combat activities of AAF military personnel require a high development level of physical qualities and morphofunctional condition as it involves long-lasting route marches with full armor on, accelerated movement with additional loads, manual execution of a large amount of work, loading ammunition, and overcoming artificial and natural obstacles. The scientists $[25,26,27,28]$ point out that a high level of physical fitness of the military personnel significantly expands their capabilities, which depend on the functional state and the negative influence of the external environment does not disrupt the homeostasis of the internal environment of the organism. Moreover, adaptation to regular physical activity leads to savings of energy resources while performing professional combat tasks and, especially, while resting, helping to accelerate the recovery process $[29,30,31]$.

According to the scientists [32,33,34], for the physical fitness of military personnel to have an effect on the results of their professional activities, it is important that the modes of functioning or actions of the corresponding 
functional systems coincide. In other words, for the motor skills, formed during physical exercises, techniques, and actions, to have an impact on the military professional activity, it is necessary that the functional systems formed during various physical exercises coincide with the functional systems being formed while performing tasks of military professional (combat) activity. Therefore, CrossFit is claimed to be an effective means of physical training of AAF officers. As indicated in the works [19, 20], the main idea of CrossFit is the functional orientation of training and, consequently, its diversity. CrossFit can be used regardless of the level of initial training, age, and gender. The scientists $[16,18]$ proposed CrossFit training aimed at the improvement of the cadets' physical fitness in the field conditions. The results of the research established the high efficiency of the developed sets in terms of the comprehensive development of the physical qualities of cadets, and also their increased interest in physical exercises in the field.

Studying the effect of CrossFit training on the physical fitness of people of different ages, genders, and professions, the scientists $[17,21]$ found its positive effect on physical development and functional capabilities of the body: expanding vascular network, improving blood composition (increasing red blood cells, hemoglobin), increasing the volume of the heart muscle, chest girth, and vital capacity, improving the activity of the central nervous system. The scientists $[16,18,25]$ prove that after CrossFit training one can do any sport and achieve high results because functional training provides basic physical training, promotes endurance, muscle strength, improves cardiovascular and respiratory systems. The results of our research confirm the findings of many scientists and expand them.

\section{Conclusions}

According to the results of the research, it is established that CrossFit classes have a positive effect on improving the morphofunctional state of paratrooper cadets. According to the average values of the body weight, vital capacity, handgrip test, heart rate, and power, life, and Robinson indexes, the performance of cadets who were engaged in CrossFit, was more increased significantly in senior years of study than the performance of cadets who were training according to the traditional system of physical training. The most pronounced effect of CrossFit training was found in the indicators of the cardiovascular system, body weight, and power indicators. A high level of the morphofunctional state of cadets will improve the efficiency of their future professional military and combat activities.

\section{Disclosure Statement}

No author has any financial interest or received any financial benefit from this research.

\section{Conflict of Interest}

The authors state no conflict of interest.

\section{REFERENCES}

[1] V. Yahodzinskyi, O. Kisiliuk, N. Sydorchuk, O. Sokolovskyi, A. Kobetiak, T. Pushkar, A. Nikitin. "Interrelation of physical, professional and combat performance of the future officers engaged in strength sports during studying". International Journal of Applied Exercise Physiology, Vol.9, No.11, 215-221, 2020. Retrieved fromhttp://www.ijaep.com/index.php/IJAE/artic le/view/1196

[2] K. Prontenko, V. Prontenko, V. Bondarenko, S. Bezpaliy, G. Bykova, O. Zeleniuk, V. Dvoretsky. "Improvement of the physical state of cadets from higher educational establishments in the Ukrainian Armed Forces due to the use of the kettlebell sport", Journal of Physical Education and Sport, Vol.17, No.1, 447-451, 2017. doi: 10.7752/jpes.2017.01067

[3] I. Bloshchynskyi, G. Griban, I. Okhrimenko, V. Stasiuk, D. Suprun, O. Nedvyha, et al. "Formation of psychophysical readiness of cadets for future professional activity", The Open Sports Sciences Journal, Vol.14, 1-8, 2021. doi: $10.2174 / 1875399 X 02114010001$

[4] A. Aandstad, R. Hageberg, O. Saether, R. O. Nilsen. "Change in anthropometrics and aerobic fitness in Air Force cadets during 3 years of academy studies", Aviating, Space, and Environmental Medicine, Vol.83, No.1, 35-41, 2012. doi: 10.3357/asem.3069.2012

[5] B. Banjevic. "Morphological characteristics and functional capabilities of Ground Forces soldiers and soldiers of the Navy of Montenegro", Sport Mont, Vol.18, No.2, 41-47, 2020. doi: $10.26773 / \mathrm{smj} .200608$

[6] A. M. Malkawi, R. M. Meertens, S. P. J. Kremers, E. F. C. Sleddens. "Dietary, physical activity and weight management interventions among active-duty military personnel: a systematic review", Military Medical Research, Vol.43, No.5, 1-12, $2018 . \quad$ doi: https://doi.org/10.1186/s40779-018-0190-5

[7] H. Kyrolainen, K. Pihlainen, J. P. Vaara, T. Ojanen, M. Santtila. "Optimizing training adaptations and performance in military environment", Journal of Science and Medicine in Sport, Vol.21, No.11, 1131-1138, 2018 doi:10.1016/j.jsams.2017.11.019

[8] S. D. Blacker, F. L. Horner, P. I. Brown, D. M. Linnane, D. M. Wilkinson, A. Wright, M. P. Rayson. "Health, fitness, and responses to military training of officer cadets in a Gulf Cooperation Council country", Military Medicine, Vol.176, No.12, 1376-1381, 2011. https://doi.org/10.7205/MILMED-D-11-00166

[9] H. Groeller, S. Burley, P. Orchard, J. A. Sampson, D. C. Billing, D. Linnane. "How effective is initial 
military-specific training in the development of physical performance of soldiers?", Journal of Strength and Conditioning Research, Vol.29, No.Suppl.11, 158-162, 2015. doi: 10.1519/JSC.0000000000001066

[10] S. Widiyawati , R. P. Lukodono , A. T. Lustyana, I. A. Pradana. "Investigation of the risk of daily officer work posture based on rapid upper limb assessment (Rula) method", International Journal of Human Movement and Sports Sciences, Vol.8, No.1, 24-31, 2020. doi: 10.13189/saj.2020.080103

[11] K. Prontenko, G. Griban, V. Prontenko, F. Opanasiuk, P. Tkachenko, Ye. Zhukovskyi, Yu. Kostyuk. "Health improvement of cadets from higher military educational institutions during kettlebell lifting activities", Journal of Physical Education and Sport, Vol.18, No.1, 298-303, 2018. doi:10.7752/jpes.2018.01040

[12] S. D. Burley, J. R. Drain, J. A. Sampson, H. Groeller. "Positive, limited and negative responders: the variability in physical fitness adaptation to basic military training", Journal of Science and Medicine in Sport, Vol.21, No.11, 1168-1172, 2018. doi:10.1016/j.jsams.2018.06.018

[13] S. Chatterjee, T. Chatterjee, D. Bhattacharyya, S. Sen, M. Pal. "Effect of heavy load carriage on cardiorespiratory responses with varying gradients and modes of carriage", Military Medical Research, Vol.26, No.5, 1-7, 2018. doi: https://doi.org/10.1186/s40779-018-0171-8

[14] J. R. Drain, J. A. Sampson, D. C. Billing, S. D. Burley, D. M. Linnane, H. Groeller. "The effectiveness of basic military training to improve functional lifting strength in new recruits", Journal of Strength and Conditioning Research, Vol.29, No.Suppl.11, 73-77, 2015. doi: 10.1519/JSC.0000000000001072

[15] D. Kyslenko, K. Prontenko, V. Bondarenko, Yu. Iukhno, R. Radzievskii, V. Prontenko, O. Kizyun. "Development of the physical qualities of future specialists in protective activities due to the use of the kettlebell sport during studies", Journal of Physical Education and Sport, Vol.17, No.2, 789-794, 2017. doi:10.7752/jpes.2018.s2159

[16] A. Galimova, M. Kudryavtsev, G. Galimov, A. Osipov, N. Astaf'ev, T. Zhavner, E. Panov, L. Zakharova, B. Dagbaev, A. Vapaeva, E. Zemba, P. Fedorova. "Increase in power striking characteristics via intensive functional training in CrossFit", Journal of Physical Education and Sport, Vol.18, No.2, 585-591, 2018. doi: 10.7752/jpes.2018.02085

[17] M. J. Gibala, P. J. Gagnon, B. C. Nindl. "Military applicability of interval training for health and performance", Journal of Strength and Conditioning Research, Vol.29, No.Suppl.11, 40-45, 2015. doi: 10.1519/JSC.0000000000001119

[18] A. Osipov, M. Kudryavtsev, K. Gatilov, T. Zhavner, Yu. Klimuk, E. Ponomareva, A. Karnaukhov. "The use of functional training - Crossfit methods to improve the level of special training of athletes who specialize in combat sambo", Journal of Physical Education and Sport, Vol.17, No.3, 2013-2018, 2017. doi: 10.7752/jpes.2017.03201

[19] J. A. Partridge, B. A. Knapp, B. D. Massengale. "An investigation of motivational variables in CrossFit facilities", Journal of Strength and Conditioning Research, Vol.28, No.6, 1714-1721, 2014. doi: 10.1519/JSC.0000000000000288
[20] A. Y. Osipov, R. S. Nagovitsyn, F. H. Zekrin, T. V. Fendel, D. A. Zubkov, T. V. Zhavner. "Crossfit training impact on the level of special physical fitness of young athletes practicing judo", Sport Mont, Vol.17, No.3, 9-12, 2019. doi: 10.26773/smj.191014

[21] M. Kudryavtsev, A. Osipov, E. Kokova, Yu. Kopylov, S. Iermakov, T. Zhavner, "The possibility of increasing cadets' physical fitness level of the educational organizations of the Ministry of Internal Affairs of Russia with the help of optimal training effects via CrossFit", Journal of Physical Education and Sport, Vol.18, No.5, 2022-2028, 2018. doi:10.7752/jpes.2018.s5300

[22] J. R. Pierce, D. W. DeGroot, T. L. Grier, K. G. Hauret, B. C. Nindl, W. B. East, B. H. Jones. "Body mass index predicts selected physical fitness attributes but is not associated with performance on military relevant tasks in U.S. Army Soldiers", Journal of Science and Medicine in Sport, Vol.20, No.Suppl.4, 79-84, 2017. doi: https://doi.org/10.1016/j.jsams.2017.08.021

[23] K. Prontenko, G. Griban, T. Liudovyk, L. Kozibroda, P. Tkachenko, Yu. Kostyuk, Ye. Zhukovskyi. "Influence of kettlebell lifting classes on the level of professionally important psychological qualities and the emotional state of cadets from higher military educational institutions", Journal of Physical Education and Sport, Vol.18, Suppl. No.2, 1055-1059, 2018. doi:10.7752/jpes.2018.s2157

[24] A. P. Hunt, M. J. Buller, M. J. Maley, J. T. Costello, I. B. Stewart. "Validity of a noninvasive estimation of deep body temperature when wearing personal protective equipment during exercise and recovery", Military Medical Research, Vol.20, No.6, 1-11, 2019. doi: https://doi.org/10.1186/s40779-019-0208-7

[25] K. Prontenko, G. Griban, A. Aloshyna, I. Bloshchynskyi, Zh. Kozina, O. Bychuk, I. Novitska, M. Korchagin. "Analysis of cadets' endurance development at higher military educational institutions during the kettlebell lifting training", Sport Mont, Vol.17, No.2, 3-8, 2019. doi 10.26773/smj.190601

[26] N. A. Grankin, Z. M. Kuznecova. Indices of functional state and reserve opportunities of cadets. "Pedagogical-Psychological and Medico-Biological Problems of Physical Culture and Sports", Vol.12, No.1, 37-46, 2017. doi: 10.14526/03_2017_232

[27] K. Prontenko, O. Kuvaldina, V. Martin, G. Griban, V. Prontenko, V. Andreychuk. "Changes in the body mass index of cadets at the higher military educational institution as a result of kettlebell lifting", Journal of Physical Education and Sport, Vol.17, No.4, 2674-2677, 2017. doi: 10.7752/jpes.2017.04308

[28] L. C. X. Martins. "Hypertension, physical activity and other associated factors in military personnel: A cross-sectional study", Baltic Journal of Health and Physical Activity, Vol.10, No.4, 162-174, 2018. doi: 10.29359/BJHPA.10.4.15

[29] S. Sammito, N. Gundlach, I. Bockelmann. "Correlation between the results of three physical fitness tests (endurance, strength, speed) and the output measured during a bicycle ergometer test in a cohort of military servicemen", Military Medical Research, Vol.12, No.3, 1-6, 2016. doi:10.1186/s40779-016-0083-4 
[30] K. Prontenko, G. Griban, A. Aloshyna, S. Bezpalyi, T. Yavorska, S. Hryshchuk, P. Tkachenko, D. Dzenzeliuk, I. Bloshchynskyi. "The physical development and functional state as the important components of the students' health", Wiadomości Lekarskie, Vol.72 No.12, part 1, 2348-2353, 2019. doi: 10.36740/WLek201912115

[31] A. G. Williams. "Effects of basic training in the British Army on regular and reserve army personnel", Journal of Strength and Conditioning Research, Vol.19, No.2, 254-259, 2005. doi:10.1519/15704.1

[32] K. Prontenko, G. Griban, V. Prontenko, V. Andreychuk, P. Tkachenko, Yu. Kostyuk, Ye. Zhukovskyi. "Kettlebell lifting as a means of physical training cadets in higher military educational institution", Journal of Physical
Education and Sport, Vol.17, No.4, 2685-2689. 2017. doi:10.7752/jpes.2017.04310

[33] M. Santtila, K. Pihlainen, J. Viskari, H. Kyrolainen. "Optimal physical training during military basic training period", Journal of Strength and Conditioning Research, Vol.29, Suppl. No.11, 154-157, 2015. doi: 10.1519/JSC.0000000000001035

[34] O. Miroshnychenko, I. Pasichnyk, A. Voznyuk, S. Kubitskyi, M. Roganova, H. Tsvietkova, I. Shorobura, I. Bloshchynskyi. "Study of Ukrainian polar explorers' psychological readiness for extreme environments at the Antarctic station", International Journal of Human Movement and Sports Sciences, Vol.8, No.6, 455-461, 2020. doi: 10.13189/saj.2020.080618 